\title{
Caldicellulosiruptor kristjanssonii sp. nov., a cellulolytic, extremely thermophilic, anaerobic bacterium
}

\author{
Sylvia Bredholt, ${ }^{1} \dagger$ Jacob Sonne-Hansen, ${ }^{1}$ Preben Nielsen, ${ }^{2}$ \\ Indra M. Mathrani ${ }^{1}$ and Birgitte K. Ahring ${ }^{1}$
} Author for correspondence: Birgitte K. Ahring. Tel: +45 45251566 . Fax: +4545932850.
e-mail: bka@ibt.dtu.dk

1 Department of
Biotechnology, The
Technical University of
Denmark, Block 113,
DK-2800 Lyngby,
Denmark
2 Enzyme Research Novo
Nordisk AV, Novo Allé,
2880 Bagsværd, Denmark

\section{INTRODUCTION}

Anaerobic micro-organisms from extreme environments and, in particular, their fermentation products and thermostable enzymes, have been the subject of much research over the past 15-20 years. Much interest has been centred on the cellulose- and hemicellulosedegrading bacteria, as these polymers constitute a large renewable resource in nature.

Many of the validly described anaerobic, thermophilic, cellulose-degrading bacteria form spores and are placed in the genus Clostridium (Wiegel, 1992). In contrast, a number of anaerobic, cellulolytic, extremely thermophilic, non-spore-forming bacteria have been isolated (Huang et al., 1998; Hudson et al., 1990;

\footnotetext{
tPresent address: MATFORSK, Norwegian Food Research Institute, Osloveien 1, N-1430 Ås, Norway.

The EMBL accession number for the 165 rRNA gene sequence of strain
} 177R1B ${ }^{\top}$ is AJ004811.
Mladenovska et al., 1995; Rainey et al., 1993a; Sissons et al., 1987; Svetlichnii \& Svetlichnaya, 1988; Svetlichnii et al., 1990; Taya et al., 1985; Wiegel, 1992). The cellulolytic strains have been mostly isolated from neutral to alkaline hot springs. Two strains were isolated from compost (Rainey et al., 1993a) and Caldicellulosiruptor owensensis was isolated from sediment taken from Owens Lake, California, USA (Huang et al., 1998). Common features of the isolates are their high temperature habitat, ability to ferment polysaccharides, high optimum growth temperature $\left(68-75^{\circ} \mathrm{C}\right)$, a maximum growth temperature lower than $85^{\circ} \mathrm{C}$, a pH range for growth between $\mathrm{pH} 4.0$ and $9 \cdot 0$, and their apparent lack of ability to form spores. By comparative 16S rDNA sequence studies, Rainey and co-workers, and later Huang and co-workers, have shown that these organisms cluster together in one group (Huang et al., 1998; Rainey et al., 1993a, b; Rainey \& Stackebrandt, 1993).

In the present study, we have characterized a new 
anaerobic, cellulolytic, extremely thermophilic bacterium, strain I77R $1 \mathrm{~B}^{\mathrm{T}}$. The physiological characteristics of this strain, phylogenetic analysis of rDNA and DNA-DNA hybridization suggest that this strain represents a new species of cellulolytic, extremely thermophilic, anaerobic bacteria, Caldicellulosiruptor kristjanssonii sp. nov., named in honour of Dr Jakob $\mathrm{K}$. Kristjansson, a substantial contributor to the ecology and biotechnology of thermophilic bacteria.

\section{METHODS}

All diagnostic tests were performed at least twice, with triplicate determinations. Mean values are reported.

Growth medium. The anaerobic medium used for cultivation was as previously described (Angelidaki et al., 1990), with the following adjustments. Avicel $\left(2 \mathrm{~g} \mathrm{l}^{-1}\right.$; microcrystalline cellulose, FMC International) was used as carbon and energy source. The medium was supplemented with $0.10 \mathrm{~g}$ yeast extract $1^{-1}$ and no cysteine was added. The medium was adjusted to $\mathrm{pH} 7.0$ and autoclaved at $140^{\circ} \mathrm{C}$ for $20 \mathrm{~min}$. Before inoculation, the medium was reduced with $0.5 \mathrm{~g} \mathrm{Na}_{2} \mathrm{~S}$ $\mathrm{l}^{-1}$ and $10 \mathrm{ml}$ vitamin solution $\mathrm{l}^{-1}$ (DSMZ medium no. 141) was added. Carbohydrate and vitamin solutions were filtersterilized and added just before inoculation. Cultures were maintained by transferring a $10 \%(\mathrm{v} / \mathrm{v})$ inoculum to fresh medium and were incubated in the dark without shaking. Fully grown cultures were removed from the incubator and stored at room temperature. Cultures were transferred at least weekly.

Isolation. Isolation was carried out anaerobically at $70^{\circ} \mathrm{C}$ and $\mathrm{pH} 7.0$ using the roll-tube technique (Hungate, 1969). Dilutions of the enrichment cultures were transferred into medium containing $2 \mathrm{~g}$ Avicel $1^{-1}$ and solidified with $11 \mathrm{~g}$ Gelrite $1^{-1}$ and $1 \mathrm{~g} \mathrm{MgCl}_{2} 1^{-1}$. Colonies were picked anaerobically with sterile Pasteur pipettes, diluted and transferred to new roll-tubes. The procedure was repeated until only one colony type was present.

Analytical methods. GC was used for identification of fermentation products; flame-ionization detection was used for short chain fatty acids and alcohols (Sørensen et al., 1991) and thermal conductivity detection was used for measurement of gases (Angelidaki et al., 1990). Lactate and formate were quantified by HPLC (Hörber et al., 1998).

Growth experiments. Growth rates were determined by measuring culture turbidity $\left(\mathrm{OD}_{578}\right)$ with cellobiose as substrate. Media with different $\mathrm{pH}$ values were obtained by varying the ratios of $\mathrm{HCO}_{3}^{-}$and $\mathrm{Na}_{2} \mathrm{CO}_{3}$ in the medium $(1 \mathrm{ml}$ of appropriate $0.3 \mathrm{M}$ buffer was added to $9 \mathrm{ml}$ medium) and the concentration of $\mathrm{CO}_{2}$ in the headspace gas. The actual $\mathrm{pH}$ of the media was measured at the experimental temperature $\left(70^{\circ} \mathrm{C}\right)$. Growth rate measurements at various $\mathrm{pH}$ values were made in the early growth phase when the $\mathrm{pH}$ of the media showed no significant changes. Lowering of $\mathrm{pH}$ occurred in late exponential phase due to accumulation of fermentation products. Cultures were adapted to each temperature and $\mathrm{pH}$ by transferring the culture to the new conditions three times before measurements were made. Growth on soluble carbon and energy substrates was determined turbidimetrically $\left(\mathrm{OD}_{578}\right)$. Growth on insoluble substrates, e.g. xylan, was determined by measurement of the increase in acetate concentration. Cultures were inoculated with $2 \cdot 5 \%(\mathrm{v} / \mathrm{v})$ from the same medium.
Microscopic examination. Agar-coated glass slides were used for phase-contrast photomicroscopy. Gram-staining was performed according to standard methods (Gerhardt, 1981). A Streptococcus species and Escherichia coli were used as positive and negative controls, respectively. Endospore formation was tested using the methods of Schink \& Zeikus (1983) and Cook et al. (1991). In addition, cultures in the exponential growth phase were transferred to an incubator at $15-20^{\circ} \mathrm{C}$ below the optimum growth temperature of the cultures to induce sporulation. Cultures with cells in the stationary growth phase were boiled for $60 \mathrm{~min}$. At intervals of 5, 10, 20, 30 and $60 \mathrm{~min}$, samples were transferred to rolltubes with Avicel as substrate and incubated at $70^{\circ} \mathrm{C}$ to determine survival. The Schaeffer-Fulton method (Gerhardt, 1981) was used for staining endospores. The Leifson method was used for staining flagella (Gerhardt, 1981). Positive controls were Clostridium thermocellum (strain DSM 4150 or ATCC 31449) for boiling experiments and Clostridium thermohydrosulfuricum strain A2 (SonneHansen et al., 1993) for flagella staining.

Tests for sulfide production. To test for sulfide production, cultures were grown in the anaerobic medium described above with $0.5 \mathrm{~g}$ cysteine- $\mathrm{HCl} \mathrm{I}^{-1}$ as reducing agent and $2 \mathrm{~g}$ cellobiose $1^{-1}$ as the carbon source. $\mathrm{Na}_{2} \mathrm{~S}$ was omitted from the medium. The medium was gassed and autoclaved for 30 $\min ; 0.1 \mathrm{ml} 2 \mathrm{M} \mathrm{Na}_{2} \mathrm{SO}_{4}, 0.1 \mathrm{ml} 2 \mathrm{M} \mathrm{Na}_{2} \mathrm{~S}_{2} \mathrm{O}_{3}$ or $0.1 \mathrm{ml} 2 \mathrm{~g}$ peptone $1^{-1}$ was then added. Controls without additions were also performed. Sulfide in the culture medium was detected using a modification of the method described by CordRuwisch (1985). Copper reagent $\left(2 \mathrm{ml} ; 5 \mathrm{mM} \mathrm{CuSO}_{4}\right.$ in $50 \mathrm{mM} \mathrm{H} \mathrm{SO}_{4}$ ) was added to $0.5 \mathrm{ml}$ culture fluid. A black precipitate of $\mathrm{CuS}$ confirmed the presence of sulfide. Positive controls were Clostridium thermohydrosulfuricum strain A2 (Sonne-Hansen et al., 1993) and Desulfovibrio gigas strain DSM $1382^{\mathrm{T}}\left(=\mathrm{NCIB} 8403^{\mathrm{T}}\right)$. The latter organism was grown on lactate.

$\mathbf{G}+\mathbf{C}$ measurements. The $\mathrm{G}+\mathrm{C}$ content $(\mathrm{mol} \%)$ of the cellular DNA of strain $177 \mathrm{R} 1 \mathrm{~B}^{\mathrm{T}}$ was measured by HPLC at the Deutsche Sammlung von Mikroorganismen und Zellkulturen (DSMZ), Braunschweig, Germany.

Phylogenetic analysis. DNA isolation, PCR amplification of the 16S rRNA gene and sequencing of the PCR product was performed at the DSMZ. The 16S rRNA nucleotide sequence of $I 77 \mathrm{R} 1 \mathrm{~B}^{\mathrm{T}}$ was aligned against a ribosomal database comprising sequences of anaerobic bacteria of the Grampositive phylum. The following $16 \mathrm{~S}$ rRNA gene sequences were applied in the final phylogenetic analysis (EMBL no. is given in parentheses): Caldicellulosiruptor saccharolyticus strain Tp8T.6331 ${ }^{\mathrm{T}}$ (L09178); strain Comp.B1 (L09179); strain SP83 (X93020); Caldicellulosiruptor owensensis strain ATCC $700167^{\mathrm{T}}$ (U80596); Caldicellulosiruptor lactoaceticus strain $6 \mathrm{~A}^{\mathrm{T}}$ (X82842); 'Anaerocellum thermophilum' strain Z1203 (L09180); strain R12.B1 (L09181); strain Wai35B1 (L09182); 'Thermoanaerobacter cellulolyticus' strain IFO 14436 (L09183); Fervidobacterium islandicum strain DSM 5733 ${ }^{\mathrm{T}}$ (M59176); Fervidobacterium gondwanense strain AB39 $^{\mathrm{T}}$ (Z49117); Thermotoga maritima strain DSM $3109^{\mathrm{T}}$ (M21774); Dictyoglomus thermophilum strain DSM 3960 (X69194); Thermoanaerobacter brockii strain DSM $1457^{\mathrm{T}}$ (L09165); Thermoanaerobacter ethanolicus strain ATCC 33223 (L09164). Corrected pair-wise evolutionary distances were computed with the correction of Jukes \& Cantor (1969). A phylogenetic tree was constructed by neighbourjoining (Saitou \& Nei, 1987). Bootstrap values were calculated for 500 phylogenetic trees. The phylogenetic analysis 
was made using facilities collected in the ARB program package (Strunk \& Ludwig, 1997).

DNA-DNA hybridization. Cells were harvested from cultures incubated overnight at $70^{\circ} \mathrm{C}$ with lactose as substrate. Chromosomal DNA was isolated according to the following protocol. Cells were washed twice in TE buffer $[10 \mathrm{mM}$ Tris(hydroxymethyl) aminomethane, $1 \mathrm{mM}$ EDTA, $\mathrm{pH}$ 8]. Egg-white lysozyme $\left(12.5 \mathrm{mg} \mathrm{ml}^{-1}\right.$; Sigma) was added and the cells were incubated at $37^{\circ} \mathrm{C}$ for $30 \mathrm{~min}$. The lysed cells were incubated at $50{ }^{\circ} \mathrm{C}$ in $1 \% \mathrm{SDS}$ and proteinase $\mathrm{K}$ $\left(0.5 \mathrm{mg} \mathrm{ml}^{-1}\right.$; Boehringer Mannheim) for several hours or overnight. After two treatments with phenol:chloroform: isoamyl alcohol $(25: 24: 1)$, DNA was extracted with chloroform, precipitated with $0 \cdot 1$ vol. sodium acetate and 2 vol. absolute ethanol and washed twice in $70 \%$ ethanol. The DNA pellets were dried, resuspended in TE buffer and incubated with RNase $\left(0.25 \mu \mathrm{g} 100 \mathrm{\mu l}^{-1}\right.$; from bovine pancreas, Boehringer Mannheim) at $37^{\circ} \mathrm{C}$ for $30 \mathrm{~min}$. The DNA was re-precipitated, washed and resuspended in TE buffer. The quality of the DNA was measured in a $0.7 \%$ agarose gel and the concentration and purity of the DNA were determined by measuring the absorbance at 260 and $280 \mathrm{~nm}$.

The DNA hybridization experiments were performed using a modification of a previously described method (Seldin \& Dubnau, 1985) with DNA of strain I77R $1 B^{\mathrm{T}}$ as a probe. The probe was prepared from $0 \cdot 1 \mu \mathrm{g}$ chromosomal DNA by nick translation (Boehringer Mannheim) and radiolabelled with $\alpha{ }^{3}{ }^{32} \mathrm{P}$-labelled deoxycytosine (Amersham). The probe was denatured just before use by heating it up to $95^{\circ} \mathrm{C}$ for $10 \mathrm{~min}$ followed by cooling in an ice-water bath.

Hybridization. To samples containing $3 \mu \mathrm{g}$ DNA in $200 \mu \mathrm{l}$ TE buffer, $200 \mu \mathrm{l} 20 \times \mathrm{SSC}(1 \times \mathrm{SSC}$ is $0.15 \mathrm{M} \mathrm{NaCl}$ plus $0.015 \mathrm{M}$ sodium citrate) was added. The samples were denatured by heating them up to $95^{\circ} \mathrm{C}$ for $15 \mathrm{~min}$ followed by cooling on ice. Nitrocellulose membranes (Highbond-N; Amersham) were soaked in $20 \times$ SSC for $60 \mathrm{~min}$ before assembling of the slotblotter. Prior to loading the denatured DNA (in triplicate), $400 \mu 110 \times$ SSC was added to the wells. Immediately after loading, the membranes were UV-fixed $\left(2000 \times 100 \mu \mathrm{J} \mathrm{cm}^{-2}\right)$ for $2 \mathrm{~min}$ in a UV Cross-linker (Hoefer). The membranes were placed in hybridization tubes containing $5 \mathrm{ml}$ hybridization solution $[2 \times \mathrm{SSC}, 1 \mathrm{mM}$ EDTA, $0.1 \%$ blocking reagent (Boehringer Mannheim)] and were pre-hybridized for $2 \mathrm{~h}$ at $65^{\circ} \mathrm{C}$. The denatured probe was added and the hybridizations were carried out overnight in a hybridization oven (Hybridizer HB-1D; Techne) at $65^{\circ} \mathrm{C}$. The membranes were then washed twice in $2 \times$ SSC and $0.1 \%$ SDS at $25^{\circ} \mathrm{C}$ followed by two washes in $0.1 \times$ SSC and $0.1 \%$ SDS at $37^{\circ} \mathrm{C}$. The membranes were wrapped in plastic foil and exposed to X-ray film (BiomaxMS; Kodak) for $24 \mathrm{~h}$. After exposure, the individual slots were cut out of the membrane and their radioactivity measured with a scintillation counter. The percentage homology was calculated using the ratio: (c.p.m. heterologous DNA/c.p.m. homologous DNA) $\times 100$. Homologous DNA was used as the probe in the hybridization experiments (Seldin \& Dubnau, 1985).

\section{RESULTS}

Strain $177 \mathrm{R}^{1 \mathrm{~B}^{\mathrm{T}}}$ was isolated from an enrichment culture grown at $78^{\circ} \mathrm{C}$ with Avicel as substrate and inoculated with a biomat sample from a slightly

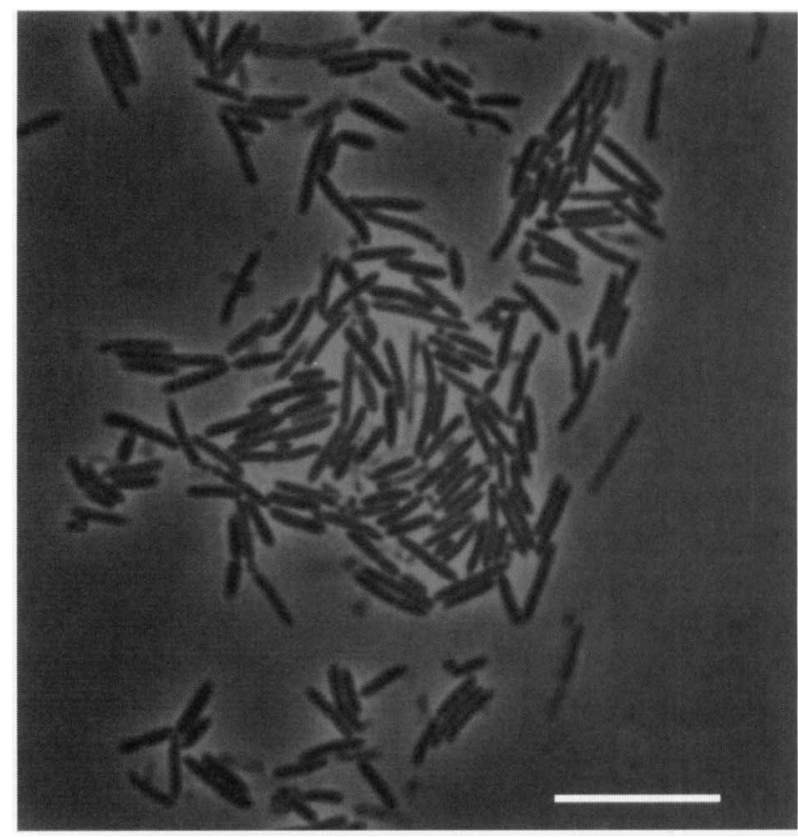

Fig. 1. Phase-contrast photomicrographs showing the isolated strain $177 \mathrm{R} 1 \mathrm{~B}^{\mathrm{T}}$. Cells were grown on $5.0 \mathrm{~g}$ xylose $\mathrm{I}^{-1}$ at $70^{\circ} \mathrm{C}$. Bar, $10 \mu \mathrm{m}$.

alkaline ( $\mathrm{pH} 8$.7) Icelandic hot spring (Sonne-Hansen \& Ahring, 1997).

\section{Colony and cell morphology of strain I77R1B}

Clearing zones around colonies in roll-tube cultures with $2 \mathrm{~g}$ Avicel $\mathrm{l}^{-1}$ were $2-4 \mathrm{~mm}$ in diameter after 9-14 d incubation, indicating solubilization of the Avicel by the actions of extracellular cellulases. Colonies were $0.5-1.0 \mathrm{~mm}$, flat, cream in colour and had a fringed edge. Liquid cultures with $2.0 \mathrm{~g}$ Avicel $1^{-1}$ were fully grown after $3-4 \mathrm{~d}$ at $78^{\circ} \mathrm{C}$. Xylose-grown cultures in exponential growth phase comprised rod-shaped cells with rounded ends, 2.8-9.4 $\mu \mathrm{m}$ long and $0.7-1.0 \mu \mathrm{m}$ wide. Cells occurred singly, in pairs and in short chains (Fig. 1). Longer cells and chains of cells were observed under non-optimal conditions of temperature and $\mathrm{pH}$. Cells were generally shorter when Avicel was used as substrate. Cells were observed both free in the liquid medium and attached to the cellulose fibres. Motility was never observed. Strain I77R1B ${ }^{T}$ had peritrichous flagella in exponential phase cultures whereas older cultures had two subterminal flagella.

Formation of endospores or spore-like structures was never observed on any of the different substrates or media or at any temperatures used. Accordingly, the strain did not survive boiling for $5 \mathrm{~min}$.

\section{Fermentation end-products}

The major fermentation end-products on $2.0 \mathrm{~g}$ Avicel $1^{-1}$ at $78^{\circ} \mathrm{C}$ were up to $16 \mathrm{mM}$ acetic acid, $3.1 \mathrm{mM}$ lactic acid, $1.1 \mathrm{mM}$ ethanol and $0.6 \mathrm{mM}$ formic acid. 


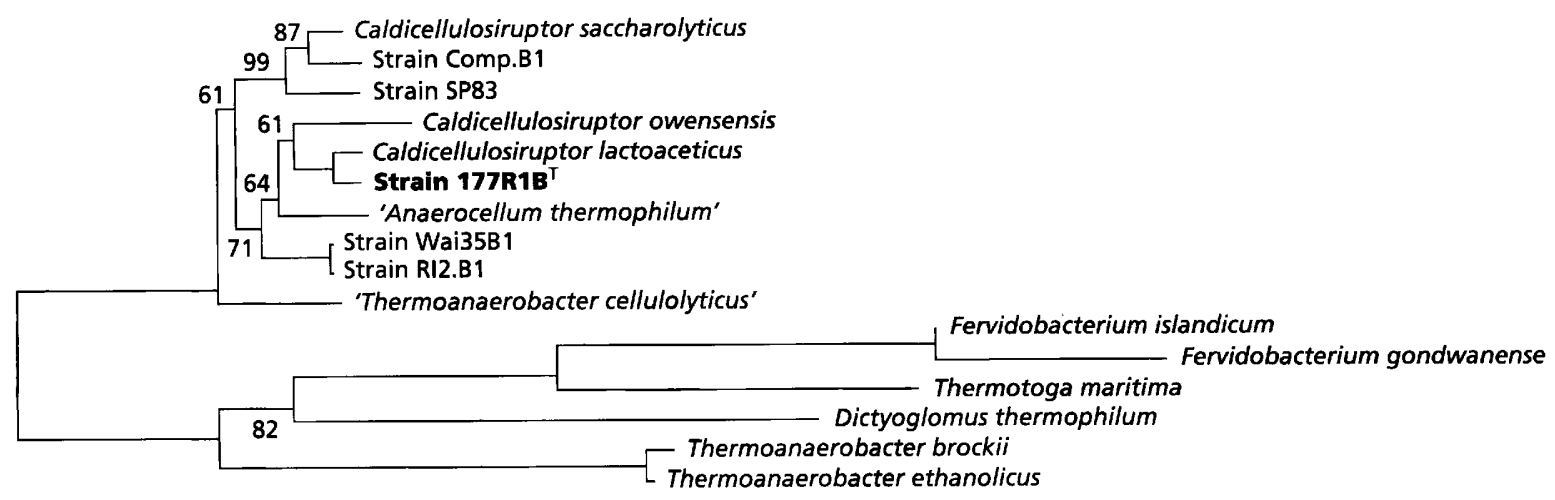

0.10

Fig. 2. Unrooted phylogenetic tree comparing the $16 \mathrm{~S}$ rRNA gene sequence of strain $177 \mathrm{R} 1 \mathrm{~B}^{\top}$ and sequences of three validly described species of the genus Caldicellulosiruptor and six genetically related species. Sequences from other thermophilic non-spore-forming bacteria were used as outgroups. Bootstrap values indicate the percentage probability for the appropriate branches of the tree. Bar, $10 \%$ corrected sequence variation.

At $70^{\circ} \mathrm{C}$ and $2 \cdot 0 \mathrm{~g}$ substrate $\mathrm{I}^{-1}$, strain $\mathrm{I} 77 \mathrm{R} 1 \mathrm{~B}^{\mathrm{T}}$ produced up to $19 \mathrm{mM}$ acetic acid from xylan, $9 \mathrm{mM}$ from cellobiose and $9 \mathrm{mM}$ from glucose. In addition to the organic acids, the strain produced hydrogen and carbon dioxide on all the different substrates tested.

\section{Optimum pH and temperature for growth}

With $2.0 \mathrm{~g}$ cellobiose $\mathrm{1}^{-1}$ as substrate, strain $\mathrm{I77R} 1 \mathrm{~B}^{\mathrm{T}}$ grew at $50-82^{\circ} \mathrm{C}$ and had an optimum growth temperature of $78^{\circ} \mathrm{C}$. At $70^{\circ} \mathrm{C}$, growth occurred at pH 5.8-8.0 with an optimum $\mathrm{pH}$ at approximately 7.0 . At the optimum temperature and $\mathrm{pH}$ with $2 \mathrm{~g}$ cellobiose $1^{-1}$ as substrate, strain I77R $1 \mathrm{~B}^{\mathrm{T}}$ had a generation time of $2 \cdot 0 \pm 0.08 \mathrm{~h}$.

\section{Substrate and nutritional requirements and $\mathbf{G}+\mathrm{C}$ content}

Strain I77R1 B ${ }^{\text {T }}$ grew on Avicel, cellobiose, dextrin, Dfructose, D-galactose, D-glucose, lactose, maltose, mannose, pectin, salicin, soluble starch, sucrose, trehalose, xylan and xylose. The strain did not grow on casein peptone, pyruvate, D-ribose, yeast extract, L-arabinose, aesculin, glycerol, inulin, lactic acid, mannitol, raffinose, L-rhamnose or sorbitol. Strain I77R1B ${ }^{\mathbf{T}}$ did not produce $\mathrm{H}_{2} \mathrm{~S}$ from any sulfuroxy anions or from peptone.

The $\mathrm{G}+\mathrm{C}$ content of strain $\mathrm{I} 77 \mathrm{R} 1 \mathrm{~B}^{\mathrm{T}}$ is $35 \pm 0.8 \mathrm{~mol} \%$.

\section{Antibiotic, hydrogen and $\mathrm{NaCl}$ sensitivity}

At $70^{\circ} \mathrm{C}$, the strain was sensitive to chloramphenicol, neomycin, penicillin-S, streptomycin, tetracycline and vancomycin, all added at $100 \mathrm{mg}^{-1}$. At $70^{\circ} \mathrm{C}$ and an antibiotic concentration of $10 \mathrm{mg} \mathrm{l}^{-1}$, the strain was still sensitive to neomycin, penicillin-S, streptomycin, tetracycline and vancomycin. $\mathrm{NaCl}(0.2 \%)$ or $0.5 \mathrm{~atm}$ overpressure of hydrogen did not inhibit growth of strain I77R1 $\mathrm{B}^{\mathrm{T}}$.

\section{Phylogenetic characterization}

The 16S rDNA was amplified by PCR and 1508 bp of the sequence were obtained. The sequence was manually aligned to sequences of clostridia and related taxa. Preliminary analysis revealed that this $16 \mathrm{~S}$ rRNA gene sequence grouped with those of other anaerobic thermophilic non-spore-forming organisms. The tree demonstrated that strain $I 77 \mathrm{R} 1 \mathrm{~B}^{\mathrm{T}}$ was related to species of the genus Caldicellulosiruptor (Fig. 2). The closest relative was Caldicellulosiruptor lactoaceticus with $98.9 \%$ sequence similarity. The distance to the type species, Caldicellulosiruptor saccharolyticus, was $95.6 \%$ and the distance to the most recently described species, Caldicellulosiruptor owensensis, was $96.5 \%$. The phylogenetic tree includes seven organisms that are not validly described. The sequence similarities between these strains and the validly described Caldicellulosiruptor species are $99 \cdot 9-94 \cdot 4 \%$.

\section{DNA-DNA hybridization}

Genomic DNA from the closest relative, Caldicellulosiruptor lactoaceticus, and from the type species of the genus, Caldicellulosiruptor saccharolyticus, were hybridized to genomic DNA from strain I77R1B ${ }^{\mathrm{T}}$. DNA of strain I $77 \mathrm{R} 1 \mathrm{~B}^{\mathrm{T}}$ shared $42 \pm 3 \%$ hybridization homology with Caldicellulosiruptor lactoaceticus and $22 \pm 2 \%$ with Caldicellulosiruptor saccharolyticus. The reliability of the method was tested using different strains of Thermoanaerobacter mathranii with nearly identical 16S rDNA. This resulted in high (86-93\%) 
hybridization homology. Likewise, very low hybridization homology $(5 \%)$ was found when hybridizing Thermoanaerobacter mathranii and Caldicellulosiruptor lactoaceticus.

\section{DISCUSSION}

Strain I77R1 B $^{\mathrm{T}}$ is anaerobic, extremely thermophilic, Gram-negative and highly saccharolytic. The strain hydrolyses crystalline cellulose and is, therefore, a 'true' cellulose degrader (Wiegel, 1992). Xylan, pectin and starch are also degraded. Based on 16S rRNA sequence analysis, strain $177 \mathrm{R} 1 \mathrm{~B}^{\mathrm{T}}$ is a member of the domain Bacteria and belongs to the subdivision containing Gram-positive bacteria with a DNA G + C content of less than $55 \mathrm{~mol} \%$ and within the radiation of members of the genus Clostridium and related taxa (Rainey et al., 1993b). Strain I77R1B ${ }^{\mathrm{T}}$ is non-sporeforming and therefore may not be included in the spore-forming genera Clostridium or Thermoanaerobacter (Lee et al., 1993). The strain does not reduce thiosulfate and, therefore, may not be included in the genus Thermoanaerobacterium (Lee et al., 1993). These characteristics are shared with the three validly described species of Caldicellulosiruptor, Caldicellulosiruptor saccharolyticus, Caldicellulosiruptor lactoaceticus and Caldicellulosiruptor owensensis, as well as other non-spore-forming, anaerobic, extremely thermophilic, cellulolytic bacteria (Huang et al., 1998; Hudson et al., 1990; Mladenovska et al., 1995; Rainey et al., 1994; Sissons et al., 1987; Svetlichnii \& Svetlichnaya, 1988; Svetlichnii et al., 1990; Taya et al., 1985; Wiegel, 1992).

Neutral-to-alkaline hot springs, naturally solar-heated environments and compost are thermal environments which select for populations of cellulolytic and xylanolytic bacteria with many similar phenotypic characteristics, independent of geographic location. There are many similarities in the phenotypes of strain I77R $1 \mathrm{~B}^{\mathrm{T}}$, Caldicellulosiruptor saccharolyticus, Caldicellulosiruptor lactoaceticus and Caldicellulosiruptor owensensis. A comparison reveals differences in cell morphology (cell length), growth, range of substrates utilized and in proportions of fermentation endproducts. Cells of Caldicellulosiruptor saccharolyticus, Caldicellulosiruptor lactoaceticus and Caldicellulosiruptor owensensis are shorter (3-4, 1.5-2.8 and $2-5 \mu \mathrm{m}$, respectively) than those of strain I77R $1 \mathrm{~B}^{\mathrm{T}}$ $(2 \cdot 8-9 \cdot 4 \mu \mathrm{m})$. Caldicellulosiruptor owensensis differs from the other strains by its production of small coccoid cells in the exponential growth phase (Huang et al., 1998). At optimum temperature and $\mathrm{pH}$ with $2.0 \mathrm{~g}$ cellobiose $1^{-1}$ as substrate, strain $\mathrm{I} 77 \mathrm{R} 1 \mathrm{~B}^{\mathrm{T}}$ has a maximum generation time of $2.0 \pm 0.08 \mathrm{~h}$. Under the same conditions, but with glucose as substrate, Caldicellulosiruptor owensensis has a generation time of $7.3 \mathrm{~h}$ (Huang et al., 1998). Caldicellulosiruptor lactoaceticus differs from strain $I 77 \mathrm{R} 1 \mathrm{~B}^{\mathrm{T}}$ in producing mainly lactate rather than acetate as the main endproduct and by its growth on a more limited range of carbohydrates. Strain I77R1B ${ }^{\text {T }}$ differs from Caldicellulosiruptor saccharolyticus and Caldicellulosiruptor owensensis in the spectrum of carbohydrates used for growth. Caldicellulosiruptor saccharolyticus ferments $\mathrm{L}$-arabinose and L-rhamnose, whereas strain $\mathrm{I} 77 \mathrm{R} 1 \mathrm{~B}^{\mathrm{T}}$ does not grow on these substrates. Caldicellulosiruptor owensensis differs from I77R1B ${ }^{\mathrm{T}}$, Caldicellulosiruptor saccharolyticus and Caldicellulosiruptor lactoaceticus by its ability to ferment mannitol, raffinose and Dribose. Thus, Caldicellulosiruptor lactoaceticus is more exclusively polysaccharolytic, whereas strain I77R $1 \mathbf{B}^{\mathrm{T}}$, Caldicellulosiruptor saccharolyticus and Caldicellulosiruptor owensensis are adapted to the utilize a wider range of soluble carbohydrates.

Comparative 16S rDNA sequence analysis places strain I77R1B ${ }^{\mathrm{T}}$ among species of Caldicellulosiruptor. Strain $\mathrm{I77R} 1 \mathrm{~B}^{\mathrm{T}}$ is most closely related to Caldicellulosiruptor lactoaceticus, with a sequence similarity of $98.9 \%$. DNA-DNA hybridization homology clearly separates strain $I 77 \mathrm{R}^{1} \mathrm{~B}^{\mathrm{T}}$ and its nearest relative Caldicellulosiruptor lactoaceticus and strongly supports assignment of $177 \mathrm{R} 1 \mathrm{~B}^{\mathrm{T}}$ to the genus Caldicellulosiruptor as a new species; the name Caldicellulosiruptor kristjanssonii sp. nov. is proposed.

\section{Description of Caldicellulosiruptor kristjanssonii sp. nov.}

Caldicellulosiruptor kristjanssonii (kris.tjans.son'ii. M.L. gen. n. kristjanssonii named after Dr Jakob K. Kristjansson).

Cells are rods with rounded ends, $2 \cdot 8-9 \cdot 4 \mu \mathrm{m}$ by $0.7-1.0 \mu \mathrm{m}$. Cells occur singly, in pairs or in short chains. Gram-negative. Endospores not found. Motility not observed. Two subterminal flagella. The $\mathrm{DNA} \mathrm{G}+\mathrm{C}$ composition is $35 \mathrm{~mol} \%$. When grown in roll-tubes on mineral medium plus Avicel, colonies are flat, cream in colour with a fringed edge. After 9-14 d, clearing zones around colonies are $2-4 \mathrm{~mm}$. Obligately anaerobic. The optimum, maximum ad minimum temperatures for growth are 78,82 and $45^{\circ} \mathrm{C}$, respectively. The optimum $\mathrm{pH}$ for growth is approximately 7.0 ; no growth above $\mathrm{pH} 8.0$ or below $\mathrm{pH} 5.8$. Chemo-organotroph. Grows on Avicel, cellobiose, dextrin, D-fructose, D-galactose, D-glucose, lactose, maltose, mannose, pectin, salicin, soluble starch, sucrose, trehalose, xylan and xylose. Does not utilize Dribose, L-arabinose, aesculin, glycerol, inulin, lactic acid, mannitol, pyruvate, raffinose, L-rhamnose, Dribose, sorbitol, casein peptone or yeast extract. Growth is inhibited by air, chloramphenicol, neomycin, penicillin, streptomycin, tetracycline and vancomycin. The major fermentation end-products are acetic acid, $\mathrm{H}_{2}$ and $\mathrm{CO}_{2}$, with smaller amounts of lactic acid and ethanol and trace amounts of formic acid. No $\mathrm{H}_{2} \mathrm{~S}$ from sulfate, thiosulfate or casein peptone. Habitat: microbial mats and cellulosic materials, e.g. wood or straw, in Icelandic thermal and slightly alkaline springs. Type strain is I77R1B ${ }^{\mathrm{T}}\left(=\mathrm{DSM} 12137^{\mathrm{T}}\right)$ and has been deposited in the DSMZ. 


\section{ACKNOWLEDGEMENTS}

This work was supported by the Nordic Energy Program and by the Danish Research Council (9501142).

\section{REFERENCES}

Angelidaki, I., Petersen, S. P. \& Ahring, B. K. (1990). Effects of lipids on thermophilic anaerobic digestion and reduction of lipid inhibition upon addition of bentonite. Appl Microbiol Biotechnol 33, 469-472.

Cook, G. M., Janssen, P. H. \& Morgan, H. W. (1991). Endospore formation by Thermoanaerobium brockii HTD4. Syst Appl Microbiol 14, 240-244.

Cord-Ruwisch, R. (1985). A quick method for the determination of dissolved and precipitated sulfide in cultures of sulfatereducing bacteria. J Microbiol Methods 4, 33-36.

Gerhardt, P. (1981). Manual of Methods for General Bacteriology. Washington, DC: American Society for Microbiology.

Hörber, C., Christiansen, N., Arvin, E. \& Ahring, B. K. (1998). Improved dechlorinating performance of upflow anaerobic sludge blanket reactors by incorporation of Dehalospirillum multivorans into granular sludge. Appl Environ Microbiol 64, 1860-1863.

Huang, C.-Y., Patel, B. K., Mah, R. A. \& Baresi, L. (1998). Caldicellulosiruptor owensensis sp. nov., an anaerobic, extremely thermophilic, xylanolytic bacterium. Int $J$ Syst Bacteriol 48, 91-97.

Hudson, J. A., Morgan, H. W. \& Daniel, R. M. (1990). A survey of cellulolytic anaerobic thermophiles from hot springs. Syst Appl Microbiol 13, 72-76.

Hungate, R. E. (1969). A roll-tube method for cultivation of strict anaerobes. Methods Microbiol 3, 117-132.

Jukes, T. H. \& Cantor, C. R. (1969). Evolution of protein molecules. In Mammalian Protein Metabolism, pp. 21-132. Edited by H. N. Munro. New York: Academic Press.

Lee, Y., Jain, M. K., Lee, C., Lowe, S. E. \& Zeikus, J. G. (1993). Taxonomic distinction of saccharolytic thermophilic anaerobes: description of Thermoanaerobacterium xylanolyticum gen. nov., sp. nov., and Thermoanaerobacterium saccharolyticum gen. nov., sp. nov.; reclassification of Thermoanaerobium brockii, Clostridium thermohydrosulfuricum E100-69 as Thermoanaerobacterium thermosulfurigenes comb. nov., and Thermoanaerobacter thermohydrosulfuricus comb. nov., respectively; and transfer of Clostridium thermohydrosulfuricum 39E to Thermoanaerobacter ethanolicus. Int J Syst Bacteriol 43, 41-51.

Mladenovska, Z., Mathrani, I. M. \& Ahring, B. K. (1995). Isolation and characterization of Caldicellulosiruptor lactoaceticus sp. nov., an extremely thermophilic, cellulolytic, anaerobic bacterium. Arch Microbiol 163, 223-230.

Rainey, F. A. \& Stackebrandt, E. (1993). 16S rDNA analysis reveals phylogenetic diversity among the polysaccharolytic clostridia. FEMS Microbiol Lett 113, 125-128.

Rainey, F. A., Janssen, P. H., Daniel, R. M., Morgan, H. W. \& Stackebrandt, E. (1993a). A biphasic approach to the determination of the phenotypic and genotypic diversity of some anaerobic, cellulolytic, thermophilic, rod-shaped bacteria. Antonie Leeuwenhoek 64, 341-355.

Rainey, F. A., Ward, N. L., Morgan, H. W., Toastler, R. \& Stackebrandt, E. (1993b). Phylogenetic analysis of anaerobic thermophilic bacteria: aid for their reclassification. $J$ Bacteriol 175, 4772-4779.

Rainey, F. A., Donnison, A. M., Janssen, P. H., Saul, D., Rodrigo, A., Bergquist, P. L., Daniel, R. M., Stackebrandt, E. \& Morgan, H. W. (1994). Description of Caldicellulosiruptor saccharolyticus gen. nov., sp. nov.: an obligately anaerobic, extremely thermophilic, cellulolytic bacterium. FEMS Microbiol Lett 120 , 263-266.

Saitou, N. \& Nei, M. (1987). The neighbor-joining method: a new method for reconstructing phylogenetic trees. Mol Biol Evol 4 , 406-425.

Schink, B. \& Zeikus, J. G. (1983). Clostridium thermosulfurogenes sp. nov., a new thermophile that produces elemental sulphur from thiosulphate. J Gen Microbiol 129, 1149-1158.

Seldin, L. \& Dubnau, D. (1985). Deoxyribonucleic acid homology among Bacillus polymyxa, Bacillus macerans, Bacillus azotofixans, and other nitrogen-fixing Bacillus strains. Int J Syst Bacteriol 35, 151-154.

Sissons, C. H., Sharrock, K. R., Daniel, R. M. \& Morgan, H. W. (1987). Isolation of cellulolytic anaerobic extreme thermophiles from New Zealand thermal sites. Appl Environ Microbiol 53, 832-838.

Sonne-Hansen, J. \& Ahring, B. K. (1997). Anaerobic microbiology of a slightly alkaline Icelandic hot-spring. FEMS Microbiol Ecol 23, 31-38.

Sonne-Hansen, J., Mathrani, I. M. \& Ahring, B. K. (1993). Xylanolytic anaerobic thermophiles from Icelandic hot-springs. Appl Microbiol Biotechnol 38, 537-541.

Sørensen, A. H., Winther-Nielsen, M. \& Ahring, B. K. (1991). Kinetics of lactate, acetate and propionate in unadapted and lactate-adapted thermophilic, anaerobic sewage sludge: the influence of sludge adaptation for start-up of thermophilic UASB reactors. Appl Microbiol Biotechnol 34, 823-827.

Strunk, O. \& Ludwig, W. (1995). ARB - a software environment for sequence data. Department of Microbiology, Technical University of Munich, Munich, Germany. arb@mikro.biologie.tu-muenchen.de.

Svetlichnii, V. A. \& Svetlichnaya, T. P. (1988). Dictyoglomus turgidus, sp. nov., a new extreme thermophilic eubacterium isolated from hot springs in the Uzon volcano crater. Mikrobiologiya 57, 435-441.

Svetlichnii, V. A., Svetlichnaya, T. P., Chernykn, N. A. \& Zavarzin, G. A. (1990). Anaerocellum thermophilum gen. nov., sp. nov., an extreme thermophilic cellulolytic eubacterium isolated from hot springs in the valley of Geysers. Mikrobiologiya 59, 871-879.

Taya, M., Hinoki, H., Susuki, Y., Yagi, T., Yap, M. G. S. \& Kobayashi, T. (1985). New thermophilic anaerobes that decompose crystalline cellulose. J Ferment Technol 63, 383-387.

Wiegel, J. (1992). The anaerobic thermophilic bacteria. In Thermophilic Bacteria, pp. 105-184. Edited by J. K. Kristjansson. London: CRC Press. 